\title{
Bacteria in sputum of stable severe asthma and increased airway wall thickness
}

\author{
Qingling Zhang ${ }^{1,2}$, Rowland Illing ${ }^{4}$, Christopher K Hui ${ }^{1,3}$, Kate Downey ${ }^{4}$, Denis Carr ${ }^{4}$, Martin Stearn ${ }^{5}$, Khalid Alshafi ${ }^{5}$, \\ Andrew Menzies-Gow ${ }^{3}$, Nanshan Zhong ${ }^{2}$ and Kian Fan Chung ${ }^{1,3,6^{*}}$
}

\begin{abstract}
Background: Patients with chronic asthma have thicker intrapulmonary airways measured on high resolution computed tomography (HRCT). We determined whether the presence of lower airway bacteria was associated with increased airway wall thickness.

Methods: In 56 patients with stable severe asthma, sputum specimens obtained either spontaneously or after induction with hypertonic saline were cultured for bacteria and thoracic HRCT scans obtained. Wall thickness $\left(W_{T}\right)$ and area $\left(W_{A}\right)$ expressed as a ratio of airway diameter $(D)$ and total area, respectively, were measured at five levels.

Results: Positive bacterial cultures were obtained in 29 patients, with H. influenzae, P. aeruginosa and S. aureus being the commonest strains. Logistic regression analysis showed that this was associated with the duration of asthma and the exacerbations during the past year. In airways $>2 \mathrm{~mm}$, there was no significant difference in $\mathrm{W}_{\mathrm{A}}$ $(67.5 \pm 5.4$ vs $66.4 \pm 5.4)$ and $W_{T} / D(21.6 \pm 2.7$ vs $21.3 \pm 2.4)$ between the culture negative versus positive groups. Similarly, in airways $(\leq 2 \mathrm{~mm})$, there were no significant differences in these parameters. The ratio of $\sqrt{ }$ wall area to $P_{i}$ was negatively correlated with $\mathrm{FEV}_{1} \%$ predicted $(\mathrm{p}<0.05)$.
\end{abstract}

Conclusions: Bacterial colonization of the lower airways is common in patients with chronic severe asthma and is linked to the duration of asthma and having had exacerbations in the past year, but not with an increase in airway wall thickness.

Keywords: Severe asthma, Airway wall thickness, Sputum bacteria

\section{Background}

The lower airways have until recently been considered to be a sterile environment, and in airway diseases such as bronchiectasis and COPD, the isolation of bacteria such as Haemophilus influenzae and Pseudomonas species in sputum samples by culture is not an uncommon event $[1,2]$. While these pathogens are often associated with exacerbations, they are also often present during stable phase of the airways disease indicating chronic colonisation. The isolation of bacterial pathogens in chronic asthma by culture remains understudied. In one report, $27 \%$ of asthmatic patients presenting with an exacerbation of asthma had bacteria in sputum with Streptococcus pneumonia, Streptococcus pyogenes,

\footnotetext{
* Correspondence: f.chung@imperial.ac.uk

'Airways Disease Section, National Heart \& Lung Institute, Imperial College, London, UK

Full list of author information is available at the end of the article
}

Staphylococcus aureus, Moraxella catarrhalis and Haemophilus influenzae [3]. This spectrum of bacterial species was also isolated from induced sputum samples in $15 \%$ of patients during a stable period of asthma [4]. The more sensitive technique of $16 \mathrm{~S}$ ribosomal RNA microarray to detect bacterial strains in lower airway epithelial brushings, has revealed an increase in bacterial burden and diversity in patients with mild to moderate asthma compared to non-asthmatic individuals $[5,6]$. Thus, there may be an increased propensity for asthmatics to carry more bacterial pathogens in their lower airways.

The role of pathogenic bacteria in the lower airways of patients with asthma is unclear. Bacteria through the activation of the innate immune response such as the toll-like receptors may induce the release of inflammatory cytokines such as IL-8 and TNF $\alpha$ that could induce neutrophilic inflammation. Asthma is usually 
characterised by a chronic inflammatory process that is driven by many factors including Th-2 derived cytokines and airway wall remodeling processes that results in subepithelial fibrosis and an increase in airway smooth muscle mass [7]. Bacterial infections may also contribute to airway wall remodeling through the activation of fibrosis by the release of growth factors such as TGF $\beta$, induced by bacterial lipopolysaccharide, leading to fibroblast activation and release of extracellular matrix proteins [8]. In addition, bacterial products may induce goblet cell hyperplasia and glandular hypertrophy. These changes may be reflected in an increase in airway wall thickness detectable on a high resolution computed tomogram. We therefore hypothesized that the presence of pathogenic bacteria may be associated with an increase in airway wall remodeling that would be reflected in a greater wall thickness. Previous studies using HRCT scans have reported an increase in airway wall thickness in patients with asthma, with the greatest responses seen in those with more severe disease [9-11].

We studied severe asthma patients defined as having persistent symptoms of chronic asthma with frequent exacerbations despite being on maximal treatment medications for their disease $[12,13]$. We determined the prevalence of pathogenic bacteria that can be cultured from sputum samples and measured airway wall thickness using HRCT scans.

\section{Methods}

\section{Subjects}

Patients with severe asthma were prospectively recruited from the Severe Asthma clinic at the Royal Brompton Hospital, London, over a 6-month period. Asthma was diagnosed on the basis of chronic symptoms and/or of recurrent exacerbations together with previously documented reversible airflow obstruction of $>15 \%$ either spontaneously or with treatment. Asthma was considered severe because of persistent symptoms and/or recurrent exacerbations despite the use of high dose inhaled steroid therapy, and often in addition to needing regular oral steroid therapy [13]. All patients had been attending the clinic for at least 6 months and had undergone a Severe Asthma Protocol for confirmation of the diagnosis of severe asthma [14]. Patients with an exacerbation of asthma within the last 4 weeks or with a respiratory tract infection requiring antibiotic treatment within 6 weeks were excluded. Patients with bronchiectasis as judged by a high resolution computed tomograms (HRCT) of the lungs were excluded. Patients were included in the study if they provided a sample of sputum either spontaneously or through its induction by inhalation of hypertonic saline. This project was approved by the Royal Brompton and NHLI Ethics
Committee and patients provided informed consent (REC reference: 10/H0711/63).

\section{Lung function and atopic status}

$\mathrm{FEV}_{1}$ and forced vital capacity (FVC) were measured using a spirometer (Erich Jaeger UK Ltd, Market Harborough, UK) and published predicted values [15]. Single breath diffusing capacity to carbon monoxide was measured and the transfer coefficient factor to carbon monoxide $\left(\mathrm{K}_{\mathrm{CO}}\right)$ was calculated according to transfer factor per unit alveolar volume. Lung volumes including residual volume (RV), and total lung capacity (TLC) were measured in a body plethysmograph (Master Lab; Erich Jaeger UK Ltd).

Atopy was defined by the presence of positive skinprick tests to at least one common aeroallergen including house dust mite, grass and tree pollen, cat dander and dog dander, aspergillus, alternaria and cladasporidium.

\section{Sputum culture and quantitative bacterial culture}

Sputum samples were first obtained by spontaneous production. If this was not possible, the subject then underwent a hypertonic saline challenge in order to induce sputum production [16]. Sputum plugs were separated from saliva using forceps. An aliquot of sputum was selected using a positive displacement pipette and used for quantitative bacteriological culture [17]. Sputum samples were plated and incubated at $37^{\circ} \mathrm{C}$ in an atmosphere of $5 \% \mathrm{CO}_{2}$ in air and examined for bacterial growth after 24 and 48 hours. The definition of a significant load of bacteria in the study was a level which resulted in growth to $10 \times 10^{6}$ colony-forming units $(\mathrm{cfu}) / \mathrm{ml}$ for any individual pathogenic respiratory bacteria.

In patients in whom there was a positive bacterial growth, one or more repeat sputum samples were subsequently obtained for further bacterial culture.

\section{High resolution computed tomographic (HRCT) scans}

HRCT scans were performed on full inspiration on a Somatom 'Sensation' 64-slice CT (Siemens, Erlangen, Germany) using a volume acquisition (120 KVp, $90 \mathrm{~mA}$ ) with $0.6 \mathrm{~mm}$ collimation, a pitch of 1.4 and $1 \mathrm{~mm}$ axial reconstructions. The abnormalities of intrapulmonary bronchi (wall thickness and diameter) were obtained at five selected levels according to a previously-published scoring system [18], as shown in Figure 1. The images were viewed at a window level of $-500 \mathrm{HU}$ and a window width of $1500 \mathrm{HU}$. Only the bronchi that were seen as end-on slices were selected.

At each level, one or two bronchial airways were identified which appeared least ovoid and had a short-axis 


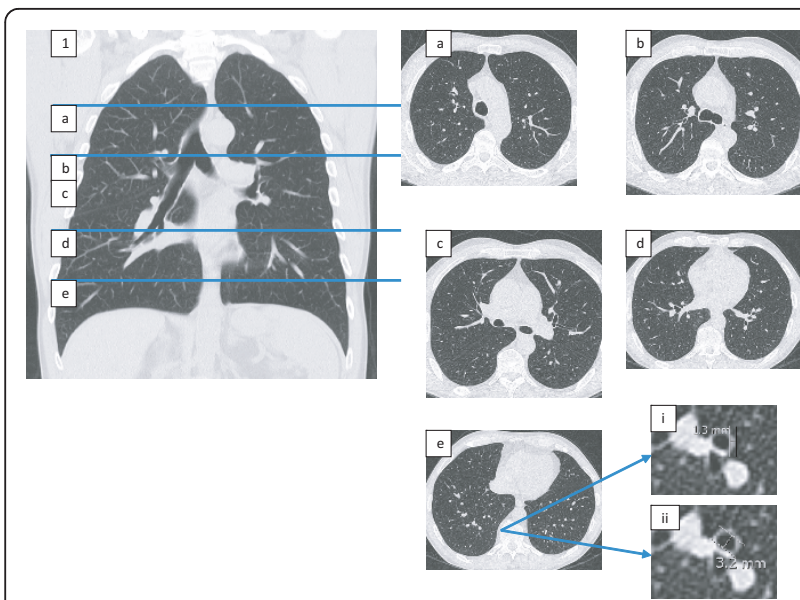

Figure 1 Coronal reconstruction from a non-contrast high resolution computed tomogram (CT) of the thorax with axial sections marked (a) at the level of the top of the aortic arch, (b) at the carina, (c) $1 \mathrm{~cm}$ below the carina, (d) at the level of the midpoint of the right pulmonary vein, and (e) $2 \mathrm{~cm}$ above the dome of the right hemi-diaphragm. The corresponding axial slices are shown (a-e). Representative measurements of airway wall (W) and diameter (D) are shown, taken from slice (e), (i) and (ii) respectively.

luminal diameter of $1 \mathrm{~mm}$ or greater. A minimum of one and maximum of two bronchi were evaluated on each side, at each level of the scan, setting the possible range of bronchi evaluated for each patient as between 10 and 20. If there were more than two candidate bronchi, then the two closest to the mediastinum were chosen. With the bronchus identified, the HRCT images were magnified and measurements made using the electronic calipers built into the picture archiving and communications system (PACS Agfa IMPAX, Germany). The measurements were done by two pulmonary radiologists who had no knowledge of the group which the subject belonged to. A decision was reached by consensus with both radiologists making the assessment together.

We divided the bronchi into 'large' airways with a luminal diameter $>2 \mathrm{~mm}$ and 'small' airways with luminal diameter $\leq 2 \mathrm{~mm}$ and made airway dimensions on these airways. Wall thickness $\left(\mathrm{W}_{\mathrm{T}}\right)$, short-axis luminal diameter $(\mathrm{L})$ and internal perimeter $\left(\mathrm{P}_{\mathrm{i}}\right)$ were measured. The total diameter (D) of each airway, total airway area $\left(\mathrm{A}_{0}\right)$, luminal area $\left(\mathrm{A}_{\mathrm{L}}\right)$ and wall area $\left(\mathrm{W}_{\mathrm{A}}\right)$ were calculated respectively, using the formulae: $\mathrm{D}=\mathrm{L}+2 \mathrm{~W}_{\mathrm{T}}, \mathrm{A}_{0}=$ $\pi\left[\left(2 \mathrm{~W}_{\mathrm{T}}+\mathrm{L}\right) / 2\right]^{2}, \mathrm{~A}_{\mathrm{L}}=\pi(\mathrm{L} / 2)^{2}, \mathrm{~W}_{\mathrm{A}}=\mathrm{A}_{0}-\mathrm{A}_{\mathrm{L}}$ and $\mathrm{Pi}=\pi \mathrm{L}$. The ratio of airway wall thickness to total diameter $\left(\mathrm{W}_{\mathrm{T}} / \mathrm{D}\right.$ ratio $)$, and the percentage of wall area $\left(\mathrm{W}_{\mathrm{A}} \%\right)$ defined as $\left(\mathrm{W}_{\mathrm{A}} / \mathrm{A}_{0}\right) * 100$ were used as representative of wall thickness $[18,19]$.

We fitted a linear relationship between $\mathrm{P}_{\mathrm{i}}$ and $\sqrt{ } \mathrm{W}_{\mathrm{A}}$ for all airways measured for each subject, and calculated
$\sqrt{\mathrm{W}_{\mathrm{A}}}$ at $\mathrm{Pi}$ of $10 \mathrm{~mm}$ from this relationship. This method condenses all airway thickness measurements into a single summary measure per subject, allowing for comparison of airway wall thickness between subjects while accounting for different airway sizes measured [20].

\section{Data analysis}

Results are given as mean \pm SEM. Pearson Chi-square test and Fisher's exact test were used to compare the data between bacteria-negative and bacteria-positive groups where appropriate. Logistic regression analysis was used to assess factors associated with the presence of positive-culture bacteria. Differences were considered significant at $\mathrm{p}<0.05$.

\section{Results}

\section{Patient characteristics}

Fifty-six patients provided sputum samples that were adequate for analysis of bacterial growth; of these, 16 produced sputum spontaneously and 40 after saline inhalation. Another 9 patients could not provide sputum by either way and were excluded from the study. Twenty-nine of the 56 patients had a significant load of pathogenic bacteria in sputum and 27 did not. A comparison of the demographics and asthma characteristics between these 2 groups is shown in Table 1 . The duration of asthma and the total number of asthma exacerbations in the past year were significantly higher in the group with significant bacterial load. There were no significant differences in gender, smoking history (defined as \% current and past smoker), obesity (defined as BMI $\geq 30 \mathrm{~kg} / \mathrm{m}^{2}$ ), nasal disease, atopy and serum IgE. Lung function was not different between the 2 groups, with a degree of chronic airflow obstruction as expected for severe asthma patients [21]. An equally high proportion of patients in both groups (more than three quarters) were taking oral prednisolone on a daily basis.

\section{Bacterial strains}

The bacterial strains detected in sputum from the 29 asthmatic patients included $H$. influenzae, P. aeruginosa, S. aureus, methicillin-resistant S. aureus (MRSA), S. pneumoniae, M. catarrhalis, Coliform, B. catarrhalis, A. xylosoxidans, K.oxytoca and S. maltophilia (Figure 2). $H$. influenzae was the most common pathogenic bacteria identified followed by $P$. aeruginosa and S. aureus. The majority had more than one bacterium cultured (16/29 patients; $55.2 \%)$ and $6 / 29(20.7 \%)$ patients had more than two.

Twenty-six of the 56 patients had their sputum samples repeated once or more than once. These were performed particularly in those that had a positive bacterial 
Table 1 Baseline demographic data

\begin{tabular}{|c|c|c|c|}
\hline Parameters & $\begin{array}{l}\text { Asthma with postive bacteria } \\
(\mathrm{n}=29)\end{array}$ & $\begin{array}{l}\text { Asthma without positive bacteria } \\
(\mathrm{n}=27)\end{array}$ & $P$ value \\
\hline Age (years) & $54.1 \pm 13.4$ & $51.9 \pm 123.8$ & NS \\
\hline Gender (male) & $31.0 \%$ & $33.3 \%$ & NS \\
\hline $\mathrm{BMI}, \mathrm{kg} / \mathrm{m}^{2}$ & $29.8 \pm 6.1$ & $28.8 \pm 5.4$ & NS \\
\hline $\mathrm{BSA}, \mathrm{m}^{2}$ & $2.0 \pm 0.3$ & $1.9 \pm 0.3$ & NS \\
\hline Obesity \% & $37.9 \%$ & $33.3 \%$ & NS \\
\hline Duration of asthma (years) & $32.9 \pm 17.2$ & $20.5 \pm 16.0^{*}$ & $P<0.05$ \\
\hline Smoking \% (current and past) & $34.5 \%$ & $48.1 \%$ & NS \\
\hline Nasal diseases\% & $20.7 \%$ & $37.0 \%$ & NS \\
\hline Atopy \% & $41.4 \%$ & $44.4 \%$ & NS \\
\hline Oral prednisolone $\%$ & $72.4 \%$ & $74.0 \%$ & NS \\
\hline Daily prednisolone (mg.day ${ }^{-1}$ ) & $18.5 \pm 16.1$ & $19.1 \pm 14.3$ & NS \\
\hline Inhaled BDP dose-equivalent (mg.day ${ }^{-1}$ ) & $2.2 \pm 1.0$ & $2.0 \pm 0.7$ & NS \\
\hline Hospitalizations in past year (Median, IQR) & $2.0(1.3-4.8)$ & $0.5(0.0-3.25)$ & NS \\
\hline Exacerbations in past year (Median, IQR) & $6.0(4.3-11.5)$ & $3.0(2.0-5.0)$ & $P<0.01$ \\
\hline $\mathrm{FEV}_{1}, \mathrm{I}$ & $1.8 \pm 0.6$ & $2.1 \pm 1.0$ & NS \\
\hline $\mathrm{FEV}_{1} \%$ predicted & $65.0 \pm 20.3 \%$ & $73.4 \pm 27.9 \%$ & NS \\
\hline FVC, I & $3.1 \pm 1.0$ & $3.4 \pm 1.2$ & NS \\
\hline FVC\% predicted & $92.3 \pm 19.3 \%$ & $95.4 \pm 18.0 \%$ & NS \\
\hline TLC \% predicted & $105.2 \pm 13.9$ & $111.9 \pm 8.2$ & NS \\
\hline RV \% predicted & $132.6 \pm 32.4$ & $148.9 \pm 41.0$ & NS \\
\hline $\mathrm{RV} / \mathrm{TLC} \%$ & $43.6 \pm 9.5$ & $45.0 \pm 10.3$ & NS \\
\hline $\mathrm{K}_{\mathrm{CO}} \%$ predicted & $92.1 \pm 14.6$ & $92.4 \pm 12.0$ & NS \\
\hline Blood eosinophil count $\left(10^{9} / \mathrm{L}\right)$ & $0.3 \pm 0.3$ & $0.2 \pm 0.2$ & NS \\
\hline Serum IgE, IU/ml & $118.0(23.2-400.8)$ & $149.5(29.8-304.8)$ & NS \\
\hline Serum IgG, g/L & $9.3 \pm 3.4$ & $9.5 \pm 2.7$ & NS \\
\hline Serum $\lg A, g / L$ & $2.3 \pm 0.9$ & $2.3 \pm 0.8$ & NS \\
\hline Serum IgM, g/L & $1.1 \pm 0.5$ & $1.2 \pm 0.5$ & NS \\
\hline
\end{tabular}

Data are presented as mean \pm SEM or median (interquartile range)

Obesity was defined as a BMl of $\geq 30 \mathrm{~kg} / \mathrm{m}^{2}$

$B D P=$ Beclomethasone dipropionate; $B M I=$ Body mass index; $B S A=$ Body surface area; $F E V_{1}=$ Forced expiratory volume in one second; $F V C=$ Forced vital capacity; $T L C=$ Total lung capacity; $R V=$ Residual volume; $K_{C O}=$ Transfer coefficient to carbon monoxide

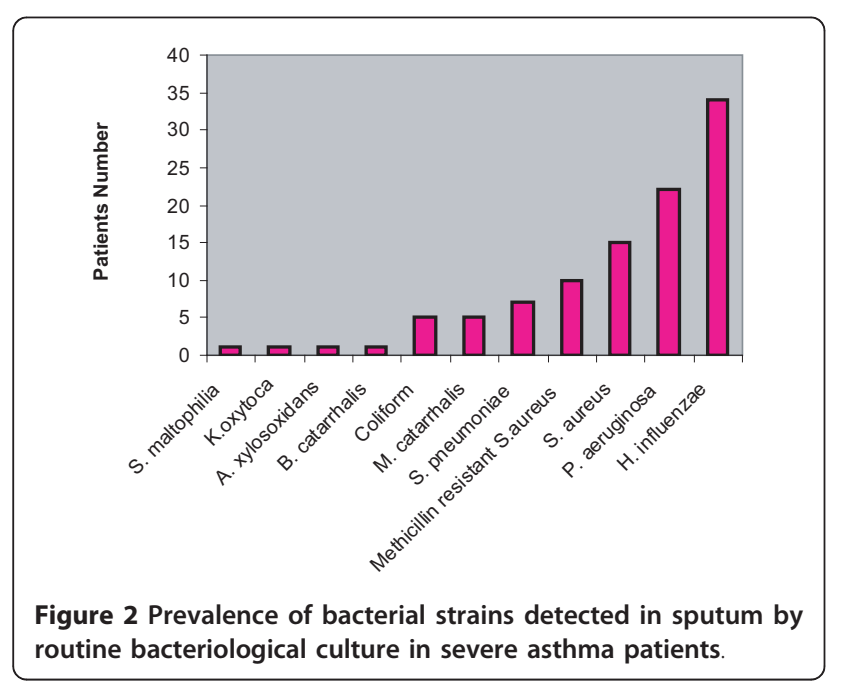

growth. In 23 of the 29 bacteria-positive subjects, 14 had the same bacterial strains grown as in their first sputum culture samples, 2 had the different bacterial strains and 7 had no repeat positive bacterial cultures. In the 3 of the 27 bacteria-negative subjects, the culture remained negative.

\section{Airway wall thickness}

The HRCT scan measurements are presented in Table 2 and Figure 3. The radiologists did not report any gross evidence of bronchiectasis in these airways. The mean $\mathrm{W}_{\mathrm{T}} / \mathrm{D}$ ratio and $\mathrm{W}_{\mathrm{A}} \%$ were $21.3 \pm 2.4$ and $66.4 \pm 5.4 \%$ in airways $>2 \mathrm{~mm}$ of asthmatics with positive bacterial cultures and $21.6 \pm 2.7$ and $67.5 \pm 5.4 \%$ for those with asthmatics without bacteria, respectively. In airways $\leq 2$ $\mathrm{mm}$ of asthma patients with bacteria, these measurements were $28.4 \pm 4.2$ and $80.2 \pm 6.9 \%$, while it was 
Table 2 Airway measurements of HRCT scans in severe asthmatics with bacteria and without bacteria

\begin{tabular}{lcc}
\hline & Asthma with positive bacteria & Asthma without positive bacteria* \\
\cline { 2 - 3 } & $\mathbf{( n = 2 9 )}$ & (n = 27) \\
\hline Total bronchi examined per group & 401 & 349 \\
\hline Large airways $>2 \mathrm{~mm}$ & & $9.2 \pm 4.5$ \\
\hline Bronchi evaluated per patient & $9.0 \pm 3.7$ & $21.6 \pm 2.7$ \\
\hline$W_{\mathrm{T}} / \mathrm{D}(\%)$ & $21.3 \pm 2.4$ & $67.5 \pm 5.4$ \\
\hline$W_{\mathrm{A}}(\%)$ & $66.4 \pm 5.4$ & $3.9 \pm 2.8$ \\
\hline Small airways $\leq 2 \mathrm{~mm}$ & & $27.3 \pm 3.7$ \\
\hline Bronchi evaluated per patient & $4.9 \pm 3.3$ & $78.7 \pm 6.6$ \\
\hline$W_{\mathrm{T}} / \mathrm{D}(\%)$ & $28.4 \pm 4.2$ & \\
\hline$W_{\mathrm{A}}(\%)$ & $80.2 \pm 6.9$ & $4.00 \pm 0.07$ \\
\hline All airways & & \\
\hline$\sqrt{W_{\mathrm{A}} \text { at } P_{\mathrm{i}} \text { of } 10 \mathrm{~mm}}$ & $3.92 \pm 0.09$ & \\
\hline
\end{tabular}

Data are presented as mean \pm SEM

$D=$ outer diameter; $P_{\mathrm{i}}=$ airway internal perimeter; $W_{\mathrm{T}}=$ wall thickness; $W_{\mathrm{A}}=$ wall area; $W_{\mathrm{A}} \%=$ percentage wall area

*There were no significant differences between the groups for any of these parameters

$27.3 \pm 3.7$ and $78.7 \pm 6.6 \%$ in asthmatics without bacteria. There were no significant differences between the groups. In addition, $\sqrt{ } \mathrm{W}_{\mathrm{A}}$ at $\mathrm{P}_{\mathrm{i}}$ of $10 \mathrm{~mm}$ was not different between the two groups (Figure 3).

When the 56 severe asthmatic subjects were analyzed together, $\sqrt{ } W_{A}$ at $P_{i}$ of $10 \mathrm{~mm}$ showed no correlation with $\mathrm{FEV}_{1} \%$ predicted, while the ratio of $\sqrt{ } \mathrm{W}_{\mathrm{A}} / \mathrm{P}_{\mathrm{i}}$ was negatively correlated with $\mathrm{FEV}_{1} \%$ predicted $(\mathrm{r}=-0.34, p$ $<0.05$, Figure 4).

Factors associated with significant bacterial culture Table 3 shows the cut-off values of variables for positive bacterial culture in sputum of severe asthmatic patients

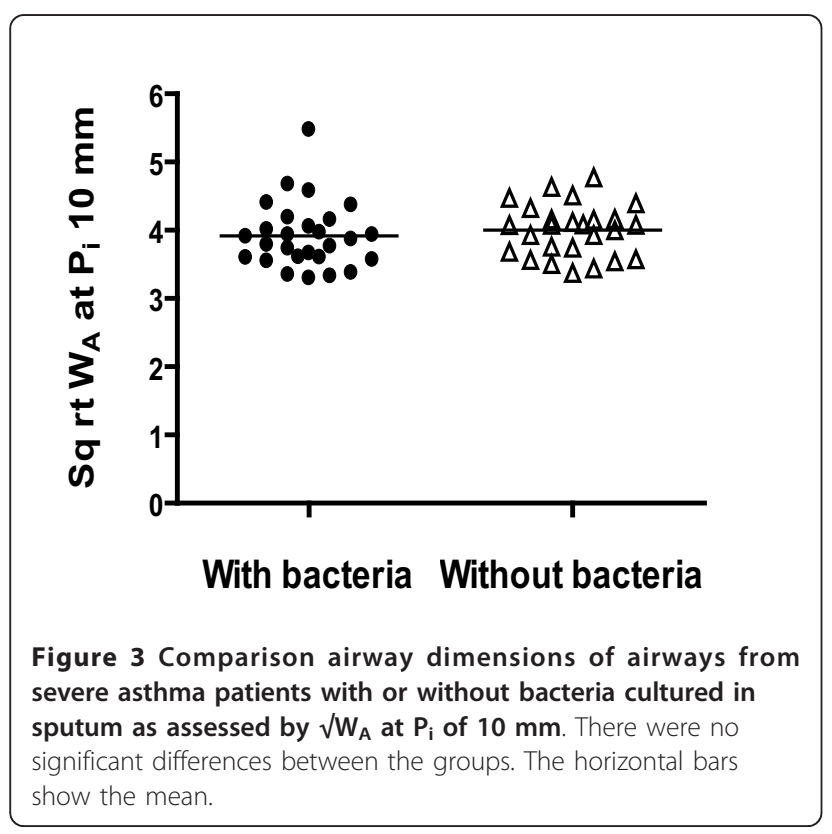

using logistic regression analysis. Univariate logistic analysis showed a significant association of the presence of bacteria on sputum culture with the duration of asthma and the number of exacerbations during the past year. Multivariate logistic analysis revealed both duration of asthma and the number of exacerbations in past year contribute to significant bacterial load in sputum, when odds ratio were adjusted for age, gender, smoking and $\mathrm{FEV}_{1}$ (\% predicted).

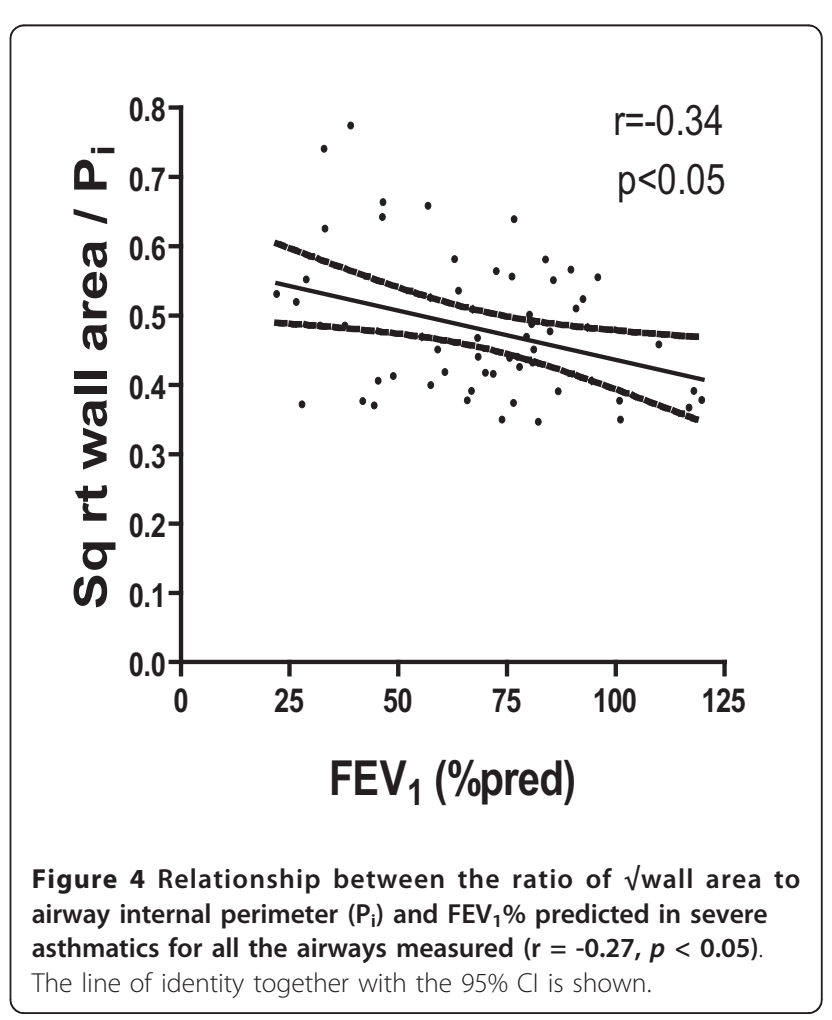


Table 3 Univariate and multivariate analyses of predictive factors for positive bacterial load

\begin{tabular}{|c|c|c|c|c|}
\hline \multicolumn{5}{|l|}{ Univariate analysis } \\
\hline Predicting factors & \multicolumn{2}{|r|}{ Odds ratio } & $95 \% \mathrm{Cl}$ & $\begin{array}{c}\mathrm{P}- \\
\text { value }\end{array}$ \\
\hline Age & \multicolumn{2}{|r|}{1.012} & $\begin{array}{l}0.971- \\
1.055 \\
\end{array}$ & NS \\
\hline Gender & \multicolumn{2}{|r|}{1.111} & $\begin{array}{l}0.362- \\
3.413\end{array}$ & NS \\
\hline Duration of asthma & \multicolumn{2}{|r|}{1.046} & $\begin{array}{l}1.005- \\
1.089\end{array}$ & 0.029 \\
\hline $\begin{array}{l}\text { Exacerbations in past } \\
\text { year }\end{array}$ & \multicolumn{2}{|r|}{1.258} & $\begin{array}{l}1.024- \\
1.544\end{array}$ & 0.029 \\
\hline Smoking & \multicolumn{2}{|r|}{1.764} & $\begin{array}{l}0.602- \\
5.171\end{array}$ & NS \\
\hline $\mathrm{FEV}_{1}$ (\% pred) & \multicolumn{2}{|r|}{0.983} & $\begin{array}{l}0.962- \\
1.005\end{array}$ & NS \\
\hline$\sqrt{ } \mathrm{W}_{\mathrm{A}}$ at $\mathrm{P}_{\mathrm{i}}$ of $10 \mathrm{~mm}$ & \multicolumn{2}{|r|}{0.627} & $\begin{array}{l}0.175- \\
2.248\end{array}$ & NS \\
\hline \multicolumn{5}{|l|}{ Multivariate analysis } \\
\hline Predicting factors & $\begin{array}{l}\text { Odds } \\
\text { ratio }\end{array}$ & $\begin{array}{l}\text { Adjusted } \\
\text { Odds } \\
\text { ratio* }\end{array}$ & $95 \% \mathrm{Cl}$ & $\begin{array}{c}\mathrm{P}- \\
\text { value }\end{array}$ \\
\hline Duration of asthma & 1.046 & 1.058 & $\begin{array}{l}1.004- \\
1.116\end{array}$ & 0.035 \\
\hline $\begin{array}{l}\text { Exacerbations in past } \\
\text { year }\end{array}$ & 1.258 & 1.630 & $\begin{array}{l}1.132- \\
2.347\end{array}$ & 0.009 \\
\hline$\sqrt{ } W_{A}$ at $P_{i}$ of $10 \mathrm{~mm}$ & 0.627 & 0.631 & $\begin{array}{l}0.168- \\
2.372\end{array}$ & NS \\
\hline
\end{tabular}

${ }^{*}$ Adjusted by age, gender, smoking and $\mathrm{FEV}_{1}$ (\% predicted)

$\mathrm{Cl}=$ confidence interval, $N S=$ non-significant,$P_{\mathrm{i}}=$ airway internal perimeter

\section{Discussion}

We found a high prevalence of bacterial colonization by potentially pathogenic microorganisms in patients with chronic severe asthma who were in a relatively stable condition and who did not suffer from bronchiectasis. Using sputum culture for bacterial detection, we found that $52 \%$ showed positive sputum cultures with predominantly $H$ influenzae, $P$ aeruginosa, $S$ aureus and $S$ pneumoniae strains. These bacterial strains are similar to those previously reported in other airway conditions associated with bacterial colonization such as bronchiectasis and COPD [22,23], but higher than in a group of mild-to-moderate asthmatics or in asthmatics during an exacerbation $[3,4]$. There were no overt differences between the positive bacterial and negative bacterial growth patients in terms of most parameters related to severe asthma, apart from a significantly longer duration of asthma and greater number of exacerbations in the past year in patients with bacterial colonization. Logistic regression analysis showed that the longer duration of asthma and the number of exacerbations in the past year were significant risk factors for bacterial colonization. In a previous study of patients with severe asthma, we found that patients with severe asthma who had significant airflow obstruction reported a longer duration of asthma than those with normal lung function, together with greater evidence of airway wall thickening measured on HRCT scan [21].

Patients with severe asthma, as well as patients with moderate to severe COPD, are more vulnerable to exacerbations, which have been associated with respiratory pathogens, particularly viruses such as rhinovirus [24]. However, atypical bacterial infections such as Mycoplasma pneumonia have also been associated with exacerbations [25]. One study reported that $27 \%$ of patients with an exacerbation of asthma had evidence of bacterial growth in sputum [3]. However, since sputum of asthmatics who are not experiencing an exacerbation of their condition also show evidence of bacterial growth in a similar or even higher prevalence [4], one could question the relevance of these bacteria in the pathogenesis of these exacerbations. Interestingly, in many of the asthmatic patients who had a positive sputum culture also showed similar bacterial profile on repeat culture, indicating that these bacteria were most likely colonizing the lower airways.

In our univariate analysis, we found that a history of previous exacerbations to be a significant risk factor for positive bacterial cultures in sputum. The importance of these bacteria in the lower airways of asthmatic patients, particularly severe asthma, is currently unclear. This is likely related to a lack of information regarding the bacterial flora of the lower airways of patients with severe asthma and its variation with time or during worsening of asthma control. Two recent studies using a sensitive technique for determining the microbiome of the lower airways by $16 \mathrm{~S}$ ribosomal RNA profiling have shown that there are bacterial species even in the lower airways of normal individuals and that this microbiome was significantly different in adult patients with asthma with evidence for pathogenic Proteobacteria, particularly Haemophilus spp [5,6].

An increase in airway wall thickness in asthma measured on HRCT scan has been related to the severity of asthma and to the degree of airflow obstruction [11,26-28]. A significant increase in airway wall thickness and size has been demonstrated in severe asthma compared to non-severe asthma and to non-asthmatic controls [9]. This study reports similar values of wall thickness expressed as $\mathrm{W}_{\mathrm{T}} / \mathrm{D}$ ratio and $\mathrm{W}_{\mathrm{A}} \%$ as those measured in our study. The increases in airway wall thickness measured on HRCT scans have been correlated with airway epithelial thickness measured on fixed tissue sections of airway biopsies, supporting the notion that these radiological abnormalities reflected airway wall remodeling processes [9]. On the other hand, the thickness of the reticular basement membrane has been 
shown to correlate with airway wall thickness measured radiologically in a mild-moderate group of asthma patients [29]. However, our studies reveal that the presence of bacteria in sputum is not associated with an increase in airway wall thickness as measured by two indices: $\mathrm{W}_{\mathrm{T}} / \mathrm{D}$ and $\mathrm{W}_{\mathrm{A}} \%$ at 2 airway sizes of or $<2 \mathrm{~mm}$ diameter. This lack of difference in airway wall thickness is unlikely to be influenced by studying different sizes of airways between the two groups since there was no difference in the $\sqrt{ }_{\text {wall }}$ area $\left(\mathrm{W}_{\mathrm{A}}\right)$ at an airway internal perimeter $\left(\mathrm{P}_{\mathrm{i}}\right)$ of $10 \mathrm{~mm}$, which represents a composite measure that takes into account the ranges of airway sizes measured for each subject [20]. Interestingly, we found a weak inverse correlation between the ratio of $\sqrt{\text { wall }}$ area $\left(\mathrm{W}_{\mathrm{A}}\right)$ to $\mathrm{P}_{\mathrm{i}}$ with $\mathrm{FEV}_{1} \%$ predicted, but not between airway wall thickness or $\sqrt{ }_{\text {wall }}$ area $\left(\mathrm{W}_{\mathrm{A}}\right)$ at an airway internal perimeter $\left(\mathrm{P}_{\mathrm{i}}\right)$ of $10 \mathrm{~mm}$ with $\mathrm{FEV}_{1} \%$ predicted, as previously reported $[11,29]$.

Our data on the persistence of these bacteria in sputum shows that a high proportion of the positive sputum were also positive on repeat sputum testing with the same bacterial species, ie 14 out of 23 patients. However, in the other 9, there was either a different bacteria isolated or no bacteria was found. Further regular assessment is needed to determine whether these bacteria may be considered as colonizing the lower airways of patients with severe asthma. There may be various reasons why patients with severe asthma may be predisposed to greater bacterial colonization of their lower airways. Innate immune responses may be defective particularly in severe asthma. Toll-like receptor 4 gene expression is significantly decreased in airway neutrophils from asthmatics compared to healthy volunteers, together with the release of inflammatory cytokines [30]. Alveolar macrophages from patients with severe asthma compared to non-severe asthma were less able to phagocytose bacteria or apoptotic cells [31,32]. In addition, the Th2-polarised response may itself have a negative impact on the innate immune host response to bacterial infections $[33,34]$. The potential effect of chronic oral corticosteroid therapy, which up to $78 \%$ of our patients were taking, may suppress innate and acquired immune responses to bacterial infections [35]. The recent studies demonstrating an increased risk of asthma patients developing invasive pneumococcal disease or pneumonia [36,37] is likely to be a reflection of reduced innate immune responses in asthma, although the exact abnormality remains to be defined.

\section{Conclusions}

Bacterial colonization of the lower airways is a common occurrence in patients with chronic stable severe asthma, but this was not related to the degree of airway wall thickness measured radiologically. We therefore conclude that bacterial colonization of asthmatic airways may not be the primary driver of airway wall remodeling, but it could be involved in other asthmatic processes.

\section{Abbreviations}

$A_{L}$ : Luminal area; BMI: Body mass index; BSA: Body surface area; D: Diameter; $\mathrm{FEV}_{1}$ : Forced expiratory volume in one second; FRC: Functional residual capacity; FVC: Forced vital capacity; HRCT: High resolution computed tomography; HU: Hounsfield Unit; $K_{c o}$ : Transfer coefficient to carbon monoxide; RV: Residual volume; TLC: Total lung capacity; $W_{\mathrm{A}}$ : Wall area; $\mathrm{W}_{\mathrm{T}}$ : Wall thickness.

\section{Acknowledgements}

This work was partly supported by the Biomedical Research Unit, Royal Brompton Hospital, London. QLZ is the recipient of a European Respiratory Society short-term Fellowship (Number 1452).

\section{Author details}

${ }^{1}$ Airways Disease Section, National Heart \& Lung Institute, Imperial College, London, UK. ${ }^{2}$ State Key Laboratory of Respiratory Diseases, The First Affiliated Hospital, Guangzhou Medical University, Guangzhou, China. ${ }^{3}$ Respiratory Biomedical Research Unit, Royal Brompton \& Harefield NHS Trust, London, UK. ${ }^{4}$ Department of Radiology, Royal Brompton \& Harefield NHS Trust, London, UK. ${ }^{5}$ Department of Microbiology, Royal Brompton \& Harefield NHS Trust, London, UK. 'Experimental Studies Unit, Imperial College, National Heart and Lung Institute, Dovehouse Street, London SW3 6LY, UK.

\section{Authors' contributions}

QZ, CKH \& AMG recruited the patients; QZ also complied the results and wrote the manuscript; RI, KD and DC analysed the HRCT scans; MS \& KA analysed the sputum cultures; NSZ contributed to the idea and to the manuscript; KFC conceived the idea, directed the research and wrote the manuscript, and is the guarantor of the paper. All authors read and approved the final manuscript.

\section{Competing interests}

AMG has been renumerated for participating on Advisory Board meetings organised by GSK, Novartis and Genentech, participated in Phase II and II studies with GSK and Novartis and has lectured for GSK, AZ and Novartis. KFC has received university grant monies from the Wellcome Trust, Medical Research Council, Asthma UK, NIH, and National Environmental Research Council (UK). He has also been renumerated for participating at Advisory Board meetings with GSK and Gilead, and for participating in speaking activities at the invitation of GSK and Novartis. Other authors have no declarations to make.

Received: 10 November 2011 Accepted: 18 April 2012 Published: 18 April 2012

\section{References}

1. Angrill J, Agusti C, de Celis R, Filella X, Rano A, Elena M, et al: Bronchial inflammation and colonization in patients with clinically stable bronchiectasis. Am J Respir Crit Care Med 2001, 164(9):1628-1632.

2. Sethi S, Murphy TF: Infection in the pathogenesis and course of chronic obstructive pulmonary disease. N Engl J Med 2008, 359(22):2355-2365.

3. Cazzola M, Matera MG, Rossi F: Bronchial hyperresponsiveness and bacterial respiratory infections. Clin Ther 1991, 13(1):157-171.

4. Wood LG, Simpson JL, Hansbro PM, Gibson PG: Potentially pathogenic bacteria cultured from the sputum of stable asthmatics are associated with increased 8-isoprostane and airway neutrophilia. Free Radic Res 2010, 44(2):146-154.

5. Huang YJ, Nelson CE, Brodie EL, Desantis TZ, Baek MS, Liu J, et al: Airway microbiota and bronchial hyperresponsiveness in patients with suboptimally controlled asthma. J Allergy Clin Immunol 2011, 127(2):372-381.

6. Hilty M, Burke C, Pedro H, Cardenas P, Bush A, Bossley C, et al: Disordered microbial communities in asthmatic airways. PLoS One 2010, 5(1):e8578. 
7. Bousquet J, Jeffery PK, Busse WW, Johnson M, Vignola AM: Asthma. From bronchoconstriction to airways inflammation and remodeling. Am J Respir Crit Care Med 2000, 161(5):1720-1745.

8. Rossol M, Heine H, Meusch U, Quandt D, Klein C, Sweet MJ, et al: LPSinduced cytokine production in human monocytes and macrophages. Crit Rev Immunol 2011, 31(5):379-446.

9. Aysola RS, Hoffman EA, Gierada D, Wenzel S, Cook-Granroth J, Tarsi J, et al: Airway remodeling measured by multidetector $\mathrm{CT}$ is increased in severe asthma and correlates with pathology. Chest 2008, 134(6):1183-1191.

10. Paganin F, Trussard V: Seneterre Eea. Chest radiography and highresolution computed tomography of the lungs in asthma. Am Rev Respir Dis 1992, 146:1084-1087.

11. Niimi A, Matsumoto H, Amitani R, Nakano Y, Mishima M, Minakuchi M, et al: Airway wall thickness in asthma assessed by computed tomography Relation to clinical indices. Am J Respir Crit Care Med 2000, 162(4 Pt 1):1518-1523.

12. Chung KF, Godard P, Adelroth E, Ayres J, Barnes N, Barnes P, et al: Difficult/ therapy-resistant asthma: the need for an integrated approach to define clinical phenotypes, evaluate risk factors, understand pathophysiology and find novel therapies. ERS Task Force on Difficult/Therapy-Resistant Asthma. European Respiratory Society [In Process Citation]. Eur Respir J 1999, 13(5):1198-1208.

13. Proceedings of the ATS workshop on refractory asthma: current understanding, recommendations, and unanswered questions. American Thoracic Society. Am J Respir Crit Care Med 2000, 162(6):2341-2351, No authors.

14. Robinson DS, Campbell DA, Durham SR, Pfeffer J, Barnes PJ, Chung KF: Systematic assessment of difficult-to-treat asthma. Eur Respir I 2003, 22(3):478-483.

15. Quanjer PH, Tammeling GJ, Cotes JE, Fabbri LM, Matthys H, Pedersen OF, et al: Symbols, abbreviations and units. Working Party Standardization of Lung Function Tests, European Community for Steel and Coal. Eur Respir J Suppl 1993, 16:85-100.

16. Jatakanon A, Uasuf C, Maziak W, Lim S, Chung KF, Barnes PJ: Neutrophilic inflammation in severe persistent asthma. Am J Respir Crit Care Med 1999, 160(5 Pt 1):1532-1539.

17. Pye A, Stockley RA, Hill SL: Simple method for quantifying viable bacterial numbers in sputum. J Clin Pathol 1995, 48(8):719-724.

18. Awadh N, Muller NL, Park CS, Abboud RT, Fitzgerald JM: Airway wall thickness in patients with near fatal asthma and control groups: assessment with high resolution computed tomographic scanning. Thorax 1998, 53(4):248-253.

19. Okazawa M, Muller N, McNamara AE, Child S, Verburgt L, Pare PD: Human airway narrowing measured using high resolution computed tomography. Am J Respir Crit Care Med 1996, 154(5):1557-1562.

20. Camp PG, Coxson HO, Levy RD, Pillai SG, Anderson W, vestbo J, et al: Sex differences in emphysema and airway disease in smokers. Chest 2009, 136(6):1480-1488.

21. Bumbacea D, Campbell D, Nguyen L, Carr D, Barnes PJ, Robinson D, et al: Parameters associated with persistent airflow obstruction in chronic severe asthma. Eur Respir J 2004, 24(1):122-128.

22. Angrill J, Agusti C, de Celis R, Rano A, Gonzalez J, Sole T, et al: Bacterial colonisation in patients with bronchiectasis: microbiological pattern and risk factors. Thorax 2002, 57(1):15-19.

23. Banerjee $D$, Khair OA, Honeybourne D: Impact of sputum bacteria on airway inflammation and health status in clinical stable COPD. Eur Respir J 2004, 23(5):685-691.

24. Dougherty RH, Fahy JV: Acute exacerbations of asthma: epidemiology, biology and the exacerbation-prone phenotype. Clin Exp Allergy 2009, 39(2):193-202.

25. Lieberman D, Lieberman D, Printz S, Ben Yaakov M, Lazarovich Z, Ohana B, et al: Atypical pathogen infection in adults with acute exacerbation of bronchial asthma. Am J Respir Crit Care Med 2003, 167(3):406-410.

26. Paganin F, Seneterre E, Chanez P, Daures JP, Bruel JM, Michel FB, et al: Computed tomography of the lungs in asthma: influence of disease severity and etiology. Am J Respir Crit Care Med 1996, 153(1):110-114.

27. Awadh N, Muller NL, Park CS, Abboud RT, Fitzgerald JM: Airway wall thickness in patients with near fatal asthma and control groups: assessment with high resolution computed tomographic scanning. Thorax 1998, 53(4):248-253.
28. Little SA, Sproule MW, Cowan MD, MacLeod K, Robertson M, Love JG, et al: High resolution computed tomographic assessment of airway wall thickness in chronic asthma: reproducibility and relationship with lung function and severity. Thorax 2002, 57(3):247-253.

29. Kasahara K, Shiba K, Ozawa T, Okuda K, Adachi M: Correlation between the bronchial subepithelial layer and whole airway wall thickness in patients with asthma. Thorax 2002, 57(3):242-246.

30. Baines KJ, Simpson JL, Scott RJ, Gibson PG: Immune responses of airway neutrophils are impaired in asthma. Exp Lung Res 2009, 35(7):554-569.

31. Fitzpatrick AM, Holguin F, Teague WG, Brown LA: Alveolar macrophage phagocytosis is impaired in children with poorly controlled asthma. $J$ Allergy Clin Immunol 2008, 121(6):1372-1378.

32. Huynh ML, Malcolm KC, Kotaru C, Tilstra JA, Westcott JY, Fadok VA, et al: Defective Apoptotic Cell Phagocytosis Attenuates PGE2 and 15-HETE in Severe Asthma Alveolar Macrophages. Am J Respir Crit Care Med 2005, 172:972-979.

33. Ramanathan M Jr, Lee WK, Spannhake EW, Lane AP: Th2 cytokines associated with chronic rhinosinusitis with polyps down-regulate the antimicrobial immune function of human sinonasal epithelial cells. Am J Rhinol 2008, 22(2):115-121.

34. Rate A, Upham JW, Bosco A, McKenna KL, Holt PG: Airway epithelial cells regulate the functional phenotype of locally differentiating dendritic cells: implications for the pathogenesis of infectious and allergic airway disease. J Immunol 2009, 182(1):72-83.

35. Oehling AG, Akdis CA, Schapowal A, Blaser K, Schmitz M, Simon HU: Suppression of the immune system by oral glucocorticoid therapy in bronchial asthma. Allergy 1997, 52(2):144-154.

36. Talbot TR, Hartert TV, Mitchel E, Halasa NB, Arbogast PG, Poehling KA, et al: Asthma as a risk factor for invasive pneumococcal disease. $N$ Engl J Med 2005, 352(20):2082-2090.

37. Juhn YJ, Kita H, Yawn BP, Boyce TG, Yoo KH, McGree ME, et al: Increased risk of serious pneumococcal disease in patients with asthma. J Allergy Clin Immunol 2008, 122(4):719-723.

doi:10.1186/1465-9921-13-35

Cite this article as: Zhang et al:: Bacteria in sputum of stable severe asthma and increased airway wall thickness. Respiratory Research 2012 13:35.

\section{Submit your next manuscript to BioMed Central and take full advantage of:}

- Convenient online submission

- Thorough peer review

- No space constraints or color figure charges

- Immediate publication on acceptance

- Inclusion in PubMed, CAS, Scopus and Google Scholar

- Research which is freely available for redistribution

Submit your manuscript at www.biomedcentral.com/submit
Ciomed Central 